\title{
Pregnancy diagnosis in the bitch: the development of a test based on the measurement of acute phase proteins in the blood
}

\author{
JM Evans ${ }^{1 *}$, DJ Anderton 2 \\ 13 Richmond Drive, Hazelwood Road, Duffield Derbyshire, DE6 6AB; \\ 2 Cambridge Veterinary Sciences Ltd Unit 8, Heny Crabb Road, \\ Littleport Ely, Cambridgeshire CB6 1SE, UK
}

(Received 12 August 1991; accepted 15 October 1992)

\begin{abstract}
Summary - Bitch owners frequently wish to know whether their bitches are pregnant following a planned mating, principally out of curiosity but also so that adequate plans can be made in advance of the anticipated whelping date. Currently abdominal palpation is the preferred method for diagnosing pregnancy in bitches, the technique being most commonly carried out 3-4 weeks post-mating. In the hands of experienced veterinarians false positives are rare, but it is difficult to be certain that a bitch is not pregnant. Problems are frequently encountered in certain breeds, fat animals and in bitches which guard their abdomen. Radiography is also used on occasion in small animal practice to confirm pregnancy but it is not until $\mathrm{d} 45$ that the foetal skeleton becomes visible. Foetal heartbeats can be seen using real time ultrasound from d 24-28 of pregnancy but the accuracy of the method depends to a great extent on the skill and expertise of the operator. It was against this background that workers at Cambridge Veterinary Sciences set out to develop a laboratory test to detect pregnancy in bitches. Work carried out by many authors has shown that progesterone, oestrogen and prolactin levels in the blood of pregnant bitches and in unmated bitches or those which have failed to become pregnant are very similar. Thus the detection of pregnancy by the measurement of hormone levels was precluded. However, earlier studies had shown that acute phase protein levels in the blood of pregnant bitches are significantly raised between $\mathrm{d} 28$ and 37 post-mating in comparison with non-pregnant animals. A method of measuring the levels of these substances in plasma using an automated analyser was perfected, and the method tested under field conditions. The background to this study and the results obtained are reviewed. Acute phase proteins are not, of course, pregnancy-specific; they can be raised in association with stress and certain disease conditions. The significance of this is discussed.
\end{abstract}

pregnancy diagnosis / protein / acute phase / bitch / whelping

Résumé - Diagnostic de gestation chez la chienne : développement d'un test basé sur la mesure de protéines de phase aigüe dans le sang. Les maîtres souhaitent fréquemment savoir si leur chienne est vraiment gestante à la suite d'un accouplement programmé; essentiellement par curiosité mais également pour préparer à l'avance la mise-bas à venir. Actuellement, la palpation abdominale est la méthode la plus courante pour le diagnostic de gestation chez la chienne, générale-

* Present address: 27 Morell Wood Drise, Belper, Derbyshire DE 560JD, UK 
ment 3-4 semaines après l'accouplement. Pour les vétérinaires expérimentés, les faux positifs sont rares mais il est difficile d'être certain que la chienne n'est pas gestante (faux négatifs). Par cette méthode, on rencontre des problèmes chez certaines races, chez les animaux gras et chez les chiennes contractant l'abdomen. Occasionnellement, la radiographie est également utilisée pour les animaux de petite taille pour confirmer la gestation mais pas avant le $45^{\circ} \mathrm{j}$ lorsque le squelette fotal devient visible. Les battements de cœur du (ou des) foetus peuvent être perçus par ultrasonographie en temps réel à partir du 24-28 j de gestation mais l'exactitude de la méthode dépend beaucoup du savoir-faire et de l'expérience de l'opérateur. C'est afin de répondre à ces difficultés que les chercheurs du Cambridge Veterinary Sciences ont entrepris le développement d'un test de diagnostic de gestation chez la chienne. Les travaux de nombreux auteurs avaient montré que les niveaux de progestérone, des cestrogènes et de prolactine étaient très similaires chez la chienne gestante et chez la chienne non saillie ou non fécondée. La détection de gestation par la mesure de l'une de ces hormones n'était donc pas réalisable. Cependant, des travaux antérieurs avaient montré que les niveaux sanguins de protéine de phase aigüe étaient significativement plus élevés chez la chienne gestante, 28-37 j après l'accouplement, que chez la chienne non-gestante. Une méthode d'analyse automatique des niveaux de ces substances dans le plasma a été mise au point et testée dans les conditions de pratique vétérinaire. Nous présenterons les fondements de cette étude et les résultats obtenus. Les protéines de phase aigües ne sont bien sûr pas spécifiques de la gestation et peuvent apparaître dans des conditions de stress ou de maladie. La signification de leur présence lors de la gestation sera discutée.

gestation / diagnostic de gestation / protéine / phase aigüe / chienne / mise-bas

\section{INTRODUCTION}

\section{The oestrous cycle in the bitch}

An understanding of the changes, internal and external, which occur during the oestrous cycle in the bitch is fundamental to an appreciation of the methods which are used to diagnose pregnancy in that species. The relevant points to note in this context are:

- in scientific terms bitches are described as monoestrous because they ovulate only once per breeding season. This unique situation is in marked contrast to polyoestrous animals like cows or seasonally polyoestrous animals like sheep;

- the cycle can be conveniently divided into 4 phases: 1), pro-oestrus is characterised by vaginal bleeding, vulval swelling and attractiveness to dogs. It lasts on average $9 \mathrm{~d} ; 2$ ), oestrus is, by definition, the period during which the bitch will accept the male. The vulva remains swollen but the discharge changes to a straw colour.
Ovulation occurs spontaneously $\approx d 2$ of oestrus which, like pro-oestrus, lasts $\approx 9 \mathrm{~d}$ on average; 3 ), oestrus merges imperceptibly into metoestrus, which is divided into 2 stages and lasts for $\approx 90 \mathrm{~d}$ in total. In metoestrus I, there are active corpora lutea in the ovaries and during metoestrus II, the uterine changes brought about by the hormonal changes associated with prooestrus, oestrus and metoestrus I, gradually subside and the uterus returns to its anoestrus state; 4), metoestrus is followed by a period of sexual inactivity called anoestrus which lasts for 3-4 months on average, but may be as short as 1 month or as long as $\mathbf{8}$ months. It is principally the duration of anoestrus which determines the frequency of the cycle in bitches.

Finally, in this connection, it should be noted that bitches frequently show signs of false pregnancy during metoestrus. Such bitches look pregnant, make nests, collect objects from around the house and usually lactate to some degree, despite the fact that they have not conceived. More than $50 \%$ of bitches show such signs, so the condition is essentially a normal abnormali- 
ty and probably exists to help the species to survive in the wild. False pregnant bitches can foster puppies from bitches which died during parturition or which have been killed whilst hunting.

The hormonal changes which occur around oestrus are shown in figure 1. The cycle is initiated by bursts of FSH which bring about a rise in oestrogen levels. Just before levels of that hormone reach their peak, progesterone levels begin to rise. These changes, possibly in concert, precipitate a pre-ovulatory LH surge. Standing oestrus, acceptance of the male occurs $\approx 2$ $\mathrm{d}$ after the LH surge - that's nicely arranged to coincide with ovulation. It seems that the bitch recognises falling oestrogen levels and rising progesterone levels and behaves accordingly. Ovulation occurs when progesterone levels are between 2 and $10 \mathrm{ng} / \mathrm{ml}$. The levels of that hormone continue to rise during metoestrus $I$ and reach initial peaks of $15-90 \mathrm{ng} / \mathrm{ml}$ by day 15-20 after the LH surge.

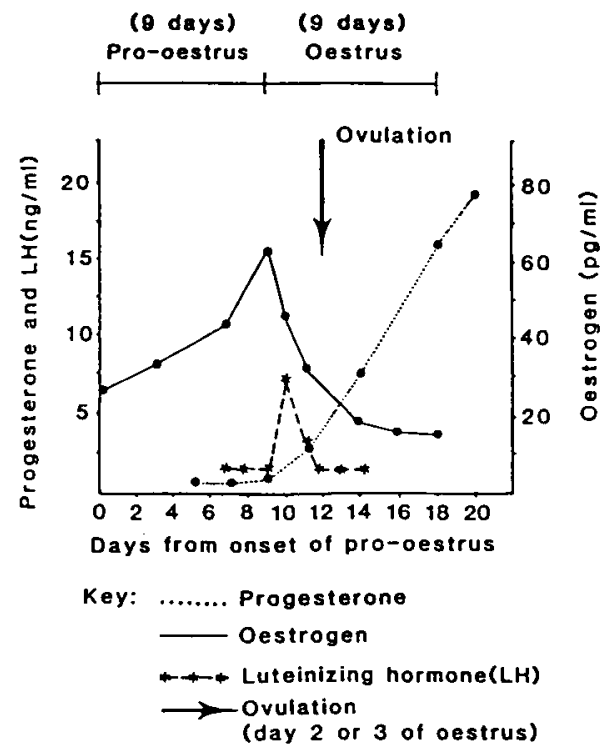

Fig 1. Hormonal events around ovulation in the bitch.
The hormonal changes which occur later in the cycle are indicated in figure 2. The salient point to note is that progesterone and oestrogen levels are virtually identical at the time when pregnancy diagnosis is needed - whether or not the bitch is pregnant (Concannon et al, 1975) and the same situation applies in respect of prolactin levels, as illustrated in figure 3 . Thus, it will be obvious that the measurement of hormone levels is not relevant in respect of pregnancy diagnosis in bitches.

\section{PREGNANCY DIAGNOSIS}

\section{The need}

Curiosity is the main reason why bitch owners want to know whether their animal is pregnant, but there are real benefits too. For example owners can:

- plan in advance, so that they can be present at the whelping or make suitable alternative arrangements;

- prepare the whelping area at leisure;

- better manage the bitch in respect of exercise, feeding and medication or, avoidance of medication.

\section{The complications}

Pregnancy diagnosis in bitches is not easy because of 2 complications.

First, as noted above, hormone levels are very similar in pregnant and nonpregnant bitches, certainly in mid metoestrus, 4-5 wk after mating when diag-nosis is most commonly required.

Secondly, canine spermatozoa can remain viable in the female genital tract for up to $7 \mathrm{~d}$. Thus a bitch presented for diagnosis 3 wk after mating may in fact only 


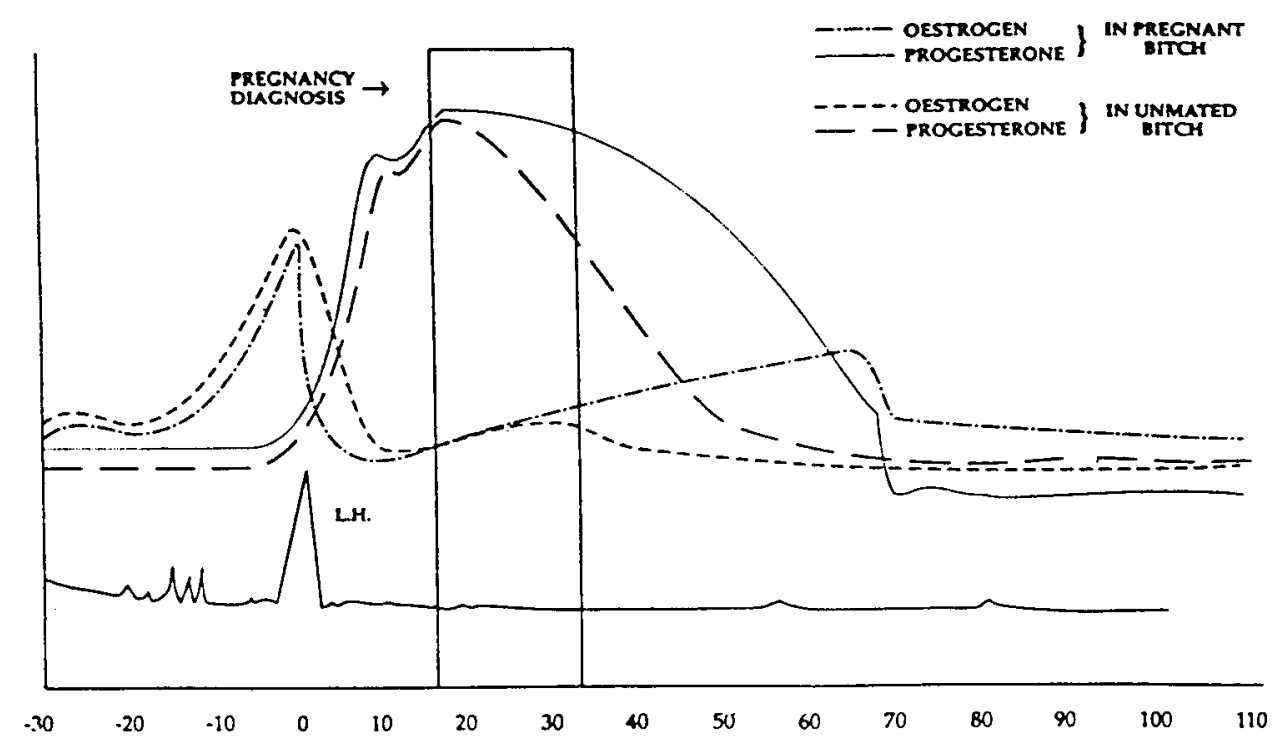

Fig 2. Comparative hormone levels in pregnant and unmated/non pregnant bitches (adapted from Jöchle, 1987).

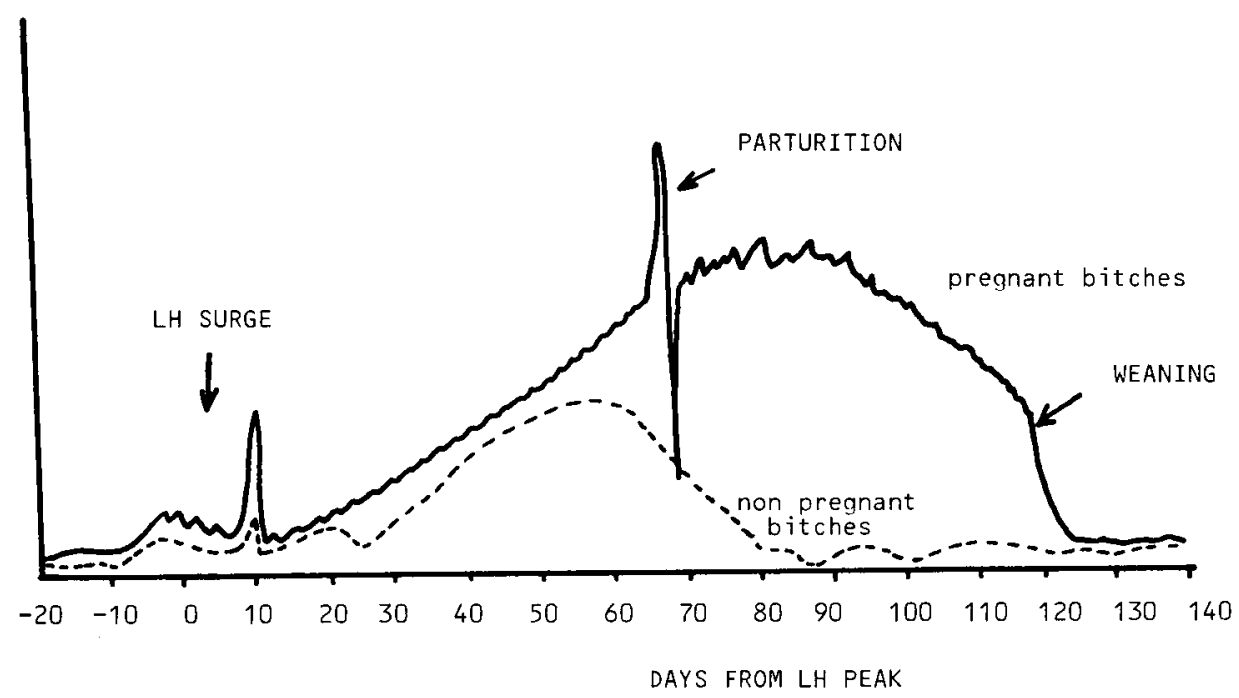

Fig 3. Prolactin levels in pregnant and non pregnant bitches (adapted from Jöchle, 1987). 
be 2 wk pregnant. It is for this reason that the traditionally quoted duration of pregnancy $63 \mathrm{~d}$ from the date of first mating is not regularly reliable. A range of potential whelping dates $58-68 \mathrm{~d}$ from the date of first mating is more likely to be correct (Feldman and Nelson, 1987), and Krzyzanowski et al (1975) reported that the duration of pregnancy may range from 54-72 d.

\section{Traditional methods}

\section{Abdominal palpation}

Nidation occurs $16 \mathrm{~d}$ post-ovulation at the earliest and from $18 \mathrm{~d}$ post-fertilisation, firm spherical enlargements develop at each nidation site. At $d 21$ of pregnancy the foetal units can be felt, resembling a string of beads each the size of a marble or bean. By d 28 the units are $25-35 \mathrm{~mm}$ in diameter with a length of only slightly enlarged uterine horn between each unit (Jones and Joshua, 1982). Most veterinary surgeons regard the interval between 3-4 wk post-mating as being the optimal time for pregnancy diagnosis by abdominal palpation.

Provided 2 or more firm 'lumps' of roughly equal size can be felt it can be said with reasonable certainty that the bitch is pregnant and it may be possible to give an indication of litter size. Figures of 87 and $73 \%$ accuracy have been quoted in respect of positive and negative pregnancy diagnoses respectively by abdominal palpation in the period 26-35 d after mating (Allen and Meredith, 1981). In practice however, experienced veterinary surgeons seldom get false positives and when this does occur it is very possible that the diagnosis was indeed right at the time, but that the puppies subsequently died and were reabsorbed. On the other hand, it is very diffi- cult to be sure that a bitch is not pregnant. From $d 30-50$ of pregnancy the uterus is more or less even in width throughout its length making palpation amongst the loops of bowel very difficult if not impossible (Feldman and Nelson, 1987).

Abdominal palpation has the advantage that it requires no special equipment but is not easy, even for veterinary surgeons with experience, in certain breeds, in fat animals and in bitches which guard their abdomen by tensing their muscles. Pregnancy diagnosis by this method is further complicated, as mentioned previously, by the fact that fertilisation may occur some time after mating so that the pregnancy is not as advanced as the mating date would indicate.

\section{Radiography}

Although it may be possible from good soft tissue films to identify uterine enlargement from wk 3 of pregnancy onwards, it must always be remembered that the uterus may be diffusely, and sometimes segmentally, enlarged in cases of metritis and pyometra. From d 45 foetal skeletons become visible radiographically and litter size can be estimated with an accuracy of $\approx 93 \%$ (Toal et al, 1986). Apart from detecting pregnancy, radiography can be used to determine foetal viability (Barr, 1988). The method is not, however, considered to be reliable in respect of the prediction of likely dystokia based on a skull versus pelvic width as the degree of pelvic relaxation which occurs at parturition cannot be estimated with any degree of accuracy (Feldman and Nelson, 1987). Finally in this respect the potentially harmful effect of ionising radiation on the developing foetus should always be borne in mind; repeated radiography is potentially hazardous and is thus best avoided except in exceptional circumstances. 


\section{Ultrasound}

A-mode and simple Doppler ultrasound techniques can be used to detect pregnancy in bitches, but these are not considered to be as accurate or provide as much information as real time ultrasound (Barr, 1988). Using the latter method, foetal units suspended in amniotic fluid and the foetal heart beats are first seen from d 24-28 of pregnancy. Foetal movements become apparent from $d 28$. Thus pregnancy can be safely diagnosed with reasonable certainty from between $\mathrm{d}$ 24-28 post-mating by the use of ultrasound. However, accuracy is very much dependant upon the skill and expertise of the operator and the sophistication of the equipment. Workers evaluating this method of pregnancy diagnosis have reported an accuracy of $94 \%$ in pregnancy diagnosis, with no false positives but only $36 \%$ for the estimation of litter size (Toal et al, 1986).

Because ultrasound can be employed safely for sequential examinations, it is without doubt the method of choice for the assessment of foetal viability (Barr, 1988), but its use in practice is limited at the present time by the cost of the necessary equipment and the need for training and the acquisition of experience with the technique.

\section{THE DEVELOPMENT OF A NEW BIOLOGICAL TEST}

\section{Background}

As noted earlier, it is not possible to detect pregnancy in the bitch by the measurement of oestrogen, progesterone or prolactin levels in the blood or urine. However, it was discovered that a major change in the levels of acute phase proteins in the blood occurs in pregnant animals but not in healthy non-pregnant bitches (fig 4). Recently a pregnancy diagnosis test based on the measurement of these proteins in

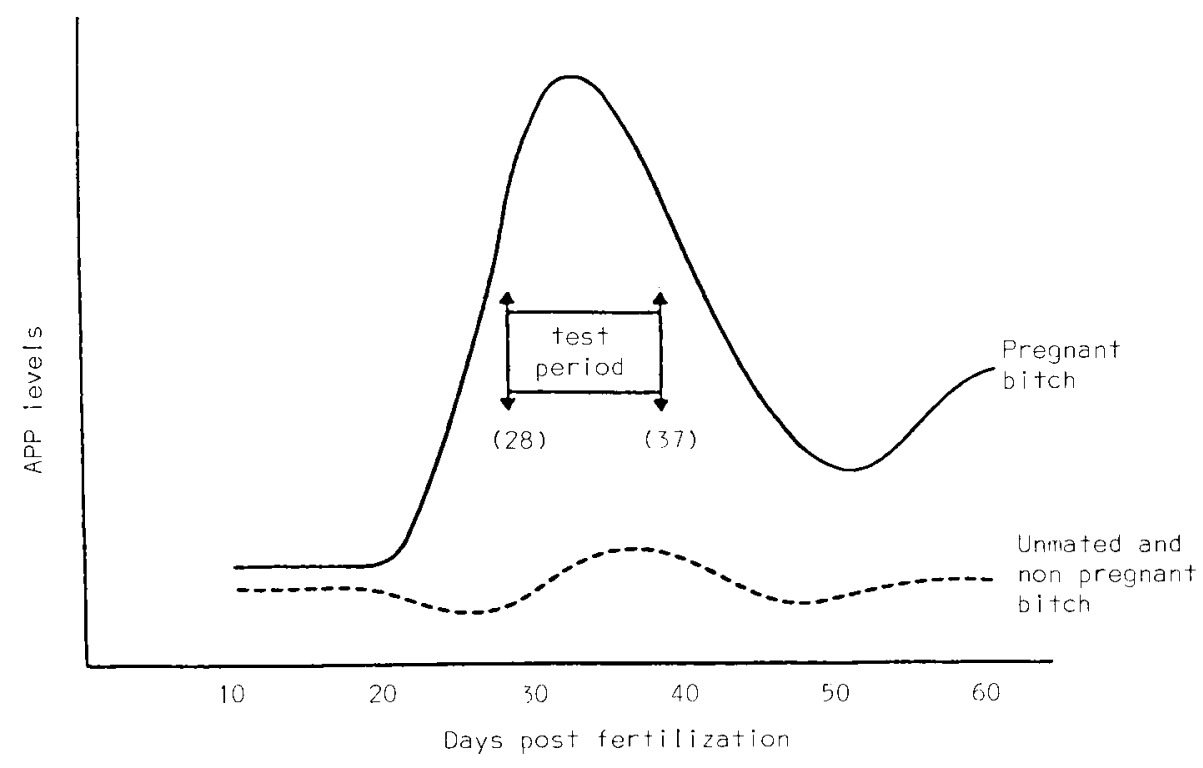

Fig 4. Acute phase protein levels in pregnant and unmated/non pregnant bitches. 
the blood has been developed by Cambridge Veterinary Sciences.

But what are acute phase proteins and what is their function?

In the early stages of an inflammatory response the concentration of a number of plasma proteins is significantly increased. These acute phase proteins (APPs) act as mediators and inhibitors of inflammation, as scavengers of cell-derived products from damaged tissues and they may also influence the immune response which accompanies inflammation (Stoddart et al, 1988). This acute phase response may be triggered by bacterial and viral infections, shock or trauma. The rise that occurs during pregnancy in bitches may be, it is postulated, in response to the blastocyst hatching which does not occur until almost 3 wk after ovulation. The reaction of the uterus to this foreign antigen appears to produce an antigenic reaction which results in uterine swellings around the blastocyst and eventually there is an elevation of acute phase protein production from the liver (Harvey, 1991).

The production of APPs is not pregnancy specific and it will be apparent that bitches suffering from some infection, eg metritis, could be falsely diagnosed as pregnant by this method as acute phase proteins will be raised in such circumstances. Trials have shown, however, that provided animals presented for pregnancy diagnosis are checked for obvious signs of illness and only healthy bitches are sampled, then problems do not generally arise, possibly because usually only healthy young bitches are used for breeding. Studies have shown that pyometra cases will show positive in the test but usually that condition occurs rather later post oestrus than when testing is advocated.

As noted earlier, APPs are serum proteins, produced by the liver, which in- crease in concentration during the acute phase response to an inflammation or infection. The response occurs in all animals but in different species the production of individual proteins can be significantly different. It is possible too that the particular proteins produced may vary with the triggering cause, be it infection, trauma or, in the case of bitches, pregnancy.

Those acute phase proteins which have been described thus far in dogs are:

$-C$ reactive protein - this was the first APP to be recognised in man and dogs but interestingly it does not appear to be an acute phase reactant in ruminants.

- Haptoglobin (Hp) - peak levels are reached $\approx 5 \mathrm{~d}$ after surgery;

- Fibrinogen - levels rise in response to trauma etc, but the severity of condition does not relate to the levels of fibrinogen in blood;

- Ceruloplasmin and seromucoid - levels in dogs double by $d$ 3 post-surgery more quickly than in man;

- Unlike other species a proteinase inhibitor is not an acute phase reactant in dogs;

- In dogs glycoprotein levels rise in response to endotoxin and surgical trauma.

In short, it should be noted that the new test relies on the detection of acute phase proteins in the blood of pregnant bitches, not a pregnancy-specific factor.

\section{THE NEW TEST IN PRACTICE}

\section{Trials}

An extensive trial involving a number of different veterinary surgeons throughout the UK and including bitches of many breeds was carried out once a reliable and practical method for the measurement of 
acute phase proteins had been developed. Over a 2-yr trial period blood samples were taken from apparently healthy mated and unmated bitches. The data obtained from the 194 samples taken from mated bitches is summarised in table $I$. The test proved to be very accurate, at least $97 \%$, in confirming pregnancy. The 4 false positives may indeed have been right at the time, the foetuses being resorbed later. The false negatives are more difficult to explain, but may have occurred as a result of pregnancy not being as advanced as was thought. The increasing accuracy seen if testing is delayed until d 33-37 post-mating substantiates the latter conclusion. With this in mind, it is advocated that where more than 1 mating has occurred over a 3-4-d period that the last $d$ of mating is counted as $d 0$. If this is done and samples are taken only between d 28-37 post-mating, to confirm an opinion based on abdominal palpation, then it is, for a biological test, very reliable indeed.

In the case of the 36 samples taken from unmated bitches, 3 false positives were obtained, probably due to some underlying inflammatory disease condition.

\section{Everyday use}

When the test is used in practice, it is important first to carry out a full clinical examination of the bitch to ensure that it is indeed healthy and not suffering from any obvious inflammatory condition. Secondly, it is necessary to carefully check the mating date(s) to ensure that the bitch was mated between 28-37 d previously. Clients with a bitch presented before $d 28$ should be asked to return it for sampling during the 28-37-d period.

A blood sample is taken in the usual way and sent to a laboratory for testing on an automated analyser. Samples arriving at the lab before noon are examined the same day, so there is little delay in knowing the result.

The test is supplied in a kit containing sufficient materials for 5 tests, and of course an instruction leaflet.

\section{Likely role}

What role will this test play in veterinary practice? What will be its place? There is

Table I. Clinical trial results.

\begin{tabular}{|c|c|c|c|c|c|c|c|}
\hline \multirow[b]{2}{*}{$\begin{array}{l}\text { Days after } \\
\text { mating }\end{array}$} & \multirow[b]{2}{*}{$\begin{array}{c}\text { No of } \\
\text { samples }\end{array}$} & \multicolumn{3}{|c|}{ Positives in test } & \multicolumn{3}{|c|}{ Negatives in test } \\
\hline & & Whelped & $\begin{array}{r}\text { Failed to whelp } \\
\text { whelp (False-ves) }\end{array}$ & $\begin{array}{c}\text { Accuracy } \\
(\%)\end{array}$ & $\begin{array}{l}\text { Failed to } \\
\text { whelp }\end{array}$ & $\begin{array}{c}\text { Whelped } \\
\text { (False+ves) }\end{array}$ & $\begin{array}{c}\text { Accuracy } \\
\text { (\%) }\end{array}$ \\
\hline $17-20$ & 3 & - & - & - & 0 & 3 & 0 \\
\hline $21-27$ & 47 & 35 & 1 & 97 & 0 & 11 & 0 \\
\hline $28-37$ & 127 & 92 & 2 & 98 & 29 & 4 & 88 \\
\hline $33-37$ & 54 & 41 & 1 & 98 & 12 & 0 & 100 \\
\hline $38-49$ & 17 & 13 & 0 & 100 & 0 & 4 & 0 \\
\hline
\end{tabular}

Note: False + ves may be due to foetal resortion or undetected underlying disease; faise-ves may be due to the fact that the stage of pregnancy was not as far advanced as thought because fertilization can occur up to 7 days postmating as spermatozoa may remain viable in the bitches genital tract for up to a week or more. 
no doubt that abdominal palpation will remain as the basic first line diagnostic method, principally because it can be done quickly and requires no expensive specialist equipment. As far as the alternatives are concerned, radiography can be used to confirm pregnancy but only reliably after $d$ 45 of gestation. Ultrasound can be used between $d$ 24-28 but is dependent on the skill of the operator and the available equipment. Good machines are expensive. Both methods can be used to determine foetal viability and litter size, but the hazards of radiation make ultrasound the method of choice in this respect.

The new bitch pregnancy test service developed by Cambridge Veterinary Sciences and marketed by Rhone Merieux in the UK which relies on the measurement of acute phase protein levels in the blood will doubtless prove useful:

- to veterinary surgeons learning the art of abdominal palpation;

- to confirm pregnancy where no foetuses can be felt;

- as an investigative tool where foetal death and foetal resorption may be considered to be the cause of infertility.

\section{REFERENCES}

Allen WE, Meredith MJ (1981) Detection of pregnancy in the bitch: a study of abdominal pal- pation, A-mode ultrasound and Doppler ultrasound techniques. J Small Anim Pract 22, 609-622

Barr FJ (1988) Pregnancy diagnosis and assessment of foetal viability in the dog: a review. J Small Anim Pract 29, 647-656

Concannon PW, Hansel W ,Visek WJ (1975) The ovarian cycle of the bitch: plasma estrogen, LH and progesterone. Biol Reprod 13, 112-121

Feldman EC, Nelson RW (1987) Canine and Feline Endocrinology and Reproduction (D Pedersen, ed) WB Saunders Co, PA, ch 14, 399-480

Harvey MJA (1991) Changes in the ovum during the time of ovulation. In: BSAVA Congr Proc, $p 50$

Jöchle $W$ (1987). The sexual cycle in the bitch. Clin Insight 2, 617-623.

Jones ED, Joshua JO (1982) Reproductive Clinical Problems in the Dog (N King, ed) Wright, Bristol, ch 6, 61-70

Krzyzanowski J, Malinowski E, Studnicki W (1975) Examinations on the period of pregnancy in dogs of some breeds. Med Wet 31, 373-374

Stoddart ME, Whicher JT, Harbour DA (1988) Cats inoculated with feline infectious peritonitis virus exhibit a biphasic acute phase plasma protein response. Vet Rec 123, 621624

Toal RL, Walker MA, Henry GA (1986) A comparison of real-time ultrasound, palpation and radiography in pregnancy detection and litter size determination in the bitch. Vet Radiol 27, 102-108 